\title{
Determinants of Voluntary International Financial Reporting Standards Adoption in Poland
}

\author{
Marcin Kedzior' $^{1}$, Malgorzata Cyganska², Dimitrios Syrrakos ${ }^{3}$ \\ ${ }^{1}$ Cracow University of Economics \\ Rakowicka Street 27, 31-510 Cracow, Poland \\ E-mail.kedziorm@uek.krakow.pl \\ ${ }^{2}$ University of Warmia and Mazury in Olsztyn \\ Oczapowskiego Street 4, 10-719 Olsztyn, Poland \\ E-mail.m.cyganska@uwm.edu.pl \\ ${ }^{3}$ Manchester Metropolitan University \\ All Saints Building, All Saints, Manchester, M15 6BH, UK \\ E-mail.D.Syrrakos@mmu.ac.uk
}

cross $^{\text {ref }}$ http://dx.doi.org/10.5755/j01.ee.31.2.24603

\begin{abstract}
The paper examines the determinants of voluntary International Financial Reporting Standards (IFRS) adoption in Poland. In doing so, it empirically confirms the impact of diverse CEO and supervisory board characteristics on voluntary IFRS adoption. The paper focuses on 446 publicly traded production companies from Poland. The analysis is based on logistic regression analysis. The empirical investigation confirms the impact on voluntary IFRS adoption of such factors as company size, international investors, international supervisory board, number of supervisory board members, CEO nationality. The paper contributes to the assessment of voluntary IFRS adoption determinants, by presenting for the first time CEO and supervisory board characteristics and their impact on voluntary International Financial Reporting Standards (IFRS) adoption, and the determinants of IFRS adoption from Central and Eastern Europe. The paper enhances existing knowledge of voluntary IFRS adoption by incorporating new CEO and supervisory board characteristics, thus closing a gap in the relevant literature. The results of the paper are significant from the supervisor's perspective, the quality of financial statements and the effectiveness of corporate governance systems.
\end{abstract}

Keywords: International Financial Reporting Standards; Chief Executive Officer; Supervisory Board; Production Companies.

\section{Introduction}

International Financial Reporting Standards (IFRS) are the most widely employed accounting standards. In some countries, non-consolidated financial statements have to be prepared according to IFRS (e.g. in Bulgaria, the Czech Republic, Estonia, Latvia and Lithuania) in others it is forbidden (e.g. Hungary). In Poland, the preparation of nonconsolidated statements in accordance to IFRS takes place on a voluntary basis.

IFRS-based financial statements increase their comparability, mitigate investors' risk as well as information risk (Parlakkaya et al., 2011; Houqe et al., 2016). Voluntary IFRS adoption increases the quality of public disclosures (Bassemir \& Novotny-Farkas, 2018), reducing the significance of private information Arsen et al., 2010). There is a positive capital markets' reaction and increased value relevance of accounting information from an investor perspective after IFRS adoption (Kouki, 2018, Petera et al., 2019). Previous studies reported that IFRS adoption have a greater impact on the quality of financial statements in countries with less advanced accounting systems (Hope et al., 2006; Rehman et al., 2014), IFRS also reduce the earnings management practices (Yang \& Abeysekera, 2018.)
It was claimed that IFRS adoption in countries with less advanced accounting systems, like Poland may enhance the reliability and quality of financial reporting (Borowski \& Kariozen 2007; Waniak-Michalak et al., 2012). IFRS increase the comparability and application of financial statements (Kedzior \& Grabinski, 2018). Up to now, research on voluntary IFRS adoption have focused on West European countries (Dumontier \& Raffournier, 1998; Andre et al., 2012; Pichler et al., 2018). There are also studies on the factors influencing IFRS use in emerging countries (Graham et al., 2017). However, there are no contributions verifying the determinants of voluntary IFRS adoption in Central and Eastern European (CEE) countries. Researchers focused on the determinants of voluntary IFRS adoption at a company level (Bassemir, 2018; Andre et al., 2012), at a country level (Hope et al., 2006; Pais \& Bonito, 2018, Damak-Ayadi et al., 2020; Salem et al., 2017; Zahid and Simga-Mugan, 2019), and both at a company and country level mostly in high developed countries. The literature does not cover the different CEO and supervisory board characteristics, which could have a potential impact on voluntary IFRS adoption. 
The purpose of this research is to identify the factors facilitating identification of IFRS, in terms of CEO and supervisory board characteristics in Polish companies.

The structure of the study is as follows. Section 2 presents the most significant research studies on the determinants of voluntary IFRS adoption. Section 3 discusses the applied research methodology involved a three-stage approach model to assess the impact and significance of identified determinants on IFRS adoption. Section 4 presents the results of empirical research. The article is completed by presenting the conclusions and references.

The paper's contribution is twofold: (i) it introduces the CEO and supervisory board characteristics that determine the use of high-quality accounting standards such as IFRS, (ii) it presents international corporate governance mechanisms which affect voluntary IFRS adoption.

\section{Literature and Hypotheses Development}

Stakeholder oriented corporate governance systems are applied in Polish companies (Collier \& Zaman, 2005). The first level of corporate governance is management, which apart from operating activities, is responsible for creating an accounting system with a specific role assigned to CEOs. CEOs not only sign financial statements, but are also responsible for company account plans and accounting policies. Supervisory boards, on the other hand, are responsible for a wide range of supervisory activities including the oversight of financial reporting.

The actual impact of company management on various aspects of financial reporting have been widely studied. A business entity's management frequently affects accounting policies in a conscious way. Managers often resort to accounting policies to signal future cash flows or to decrease the probability of debt covenant violation (Young, 1998). Accounting policies are also used to justify management's high bonuses (Inoue \& Wayne, 1996). It should be noted that accounting policies can be used both to increase and decrease company earnings (Astami \& Tower, 2006; Lo et al., 2017). choices made in the process of accounting valuations at fair value increase the ability to manage profits in time, or even manipulate them (Barth \& Taylor, 2010). When managers apply the concept of fair value, measurements in accounting do not always meet neutrality criteria (Baluch et al., 2011; Khurana \& Kim, 2003), especially when a business entity applies earnings management (Salvary, 2006). Managers are actively engaged in exerting influence on the quality and quantity of disclosures. It should be noted that some executives "manage" the volumes of disclosed financial information (Choi \& Meek, 2005; Nobes \& Stadler, 2015). Lang and Lundholm (2000) found out that the range of disclosed information is wider when a publicly traded company intends to sell a package of shares in capital markets. According to Broberg et al. (2010), companies with high levels of management ownership disclose less information than other entities. In contrast to managers, a supervisory board is mainly engaged in monitoring the process of financial reporting (Pathak \& Sun, 2013; Cho \& Rui, 2009; Anderson et al., 2004; Leuz \& Wustemann, 2003). The Securities and Exchange Commission, the Financial Accounting Standards Board as well as the world's major stock exchanges continuously stress the significance of supervisory boards in overseeing the activities of business entities (Anderson et al., 2004). This process includes the oversight of alternative accounting solutions, accounting policies with regard to disclosures, internal control processes and the selections of independent auditors. Vafeas (2000) shares the same view on the basic role of supervisory boards. Supervisory boards are responsible for assuring the quality of information presented in financial reports. According to Yang et al. (2011), a supervisory board's main objective is to monitor managers' behaviour, overview and audit financial statements submitted by directors, oversee company assets as well as assess and monitor the finances of business entities. Cho and Rui (2009) believe that a supervisory board should make sure that an entity's financial and operational condition is presented accurately, fairly and completely. The effectiveness of control mechanisms relies heavily on the independence of supervisory boards (Pathak \& Sun, 2013). Well-functioning supervisory boards reduce information asymmetry (Ilieva et al., 2018). The quality of supervision is generally improved if it is exercised by women and persons with academic experience (Ran et al., 2015). As the CEO and supervisory board may be conditioned by the size and the way of organizing the company, we included into our analysis also company size and investor characteristics, in terms of nationality.

\section{Company Size}

Larger companies incur lower information production costs as well as lower costs of competitive disadvantage associated with their disclosures (Andre et al., 2012), hence they find it easier to meet stricter requirements related to disclosures according to IFRS. The necessity of a greater number of disclosures results from the fact that large companies acquire financing from foreign capital markets. Therefore, IFRS adoption can be treated as a component of corporate governance, which is significant in the case of external financing, especially for big companies (Francis et al., 2008a). In addition, high political costs in large companies support the use of IFRS (Matonti \& Iuliano, 2012). Bassemir (2018) notes that big firms usually sell more products abroad and have more overseas subsidiaries, which increases information requirements as well as agency costs. Hence, a greater number of disclosures and IFRS adoption is more possible (Tarca, 2004). Larger companies also possess the necessary financial resources needed to implement IFRS (Pichler et al., 2018). Thus, it is hypothesized that:

H1: Larger companies are more frequently inclined to voluntarily adopt IFRS than smaller entities.

\section{International Investor}

According to the International Accounting Standard Board (IASB), globally harmonised accounting standards have a positive impact on decreasing information asymmetry between national and international participants of capital markets, especially in emerging markets (Bova, 2007). Covrig et al. (2007) noted that companies, which voluntarily adopt IFRS, have a greater potential to attract foreign investors. They disclose more information, which is presented according to widely used standards. 
According to Bagaev (2006), emerging markets can face the problem of the lack of foreign investment due to limited confidence in the quality of disclosures. Therefore, investors frequently require local businesses to adopt IFRS or US GAAP. Foreign shareholders particularly insist on using IFRS if their shareholding is dispersed (Pichler et al., 2018). They also rely heavily on high-quality, global accounting standards that are familiar with and understand as opposed to local standards (Matonti \& Iuliano, 2012). This phenomenon is intensified if the foreign parent company also uses IFRS. Klai and Omri (2013) stress that foreign investors have a positive impact on the quality of accounting in emerging markets as well as on earnings quality and transparency. Firth et al. (2007) confirm investors' impact on the earnings response coefficients and discretionary accruals and provide empirical evidence confirming a positive correlation between earnings quality and foreign shareholding. On the other hand, An and Naughton (2007) provide empirical evidence confirming a positive correlation between foreign investor share ownership and the conservatism of financial reporting. Therefore, they will strive to improve the quality of accounting in local markets, so the likelihood of using IFRS increases Thus, it is hypothesized that:

H2: Companies with international ownership are more supportive of IFRS adoption

\section{Number of Supervisory Board Members}

According to Chiraz and Anis (2012), there is a correlation between board size and earnings management. Larger boards are often composed of experienced financial experts. According to Bouchareb et al. (2014), large boards have the ability to monitor earnings management, and their experienced administrators are capable of reducing its impact. Similar results were obtained by Abbadi et al. (2016).

Research conducted by Karagul and Yonet (2012), show that the scope of voluntary disclosures is positively correlated with the size of the board and the number of its independent members (Karagul \& Yonet, 2012). According to Upadhyay and Sriram (2011), the supervisory board size has a positive effect on the transparency of information reported by the entity. On the other hand empirical research indicates that small supervisory boards contribute to increasing the informativeness of earnings (Vafeas, 2000). Attention should be drawn to correlation between the scope of voluntary disclosures and supervisory board size. Generally, larger supervisory boards have a positive impact on accounting quality and will therefore be more likely to voluntarily apply high-quality accounting standards such as IFRS. Thus, it is hypothesized that:

H3: The scope of IFRS application is broader for companies with numerous supervisory board members.

\section{International Supervisory Board}

Palmer and Varner (2007) identified a growing number of international supervisory boards in European business entities. This trend may prevail as a result of the increasing volumes of sales in overseas markets (Davarcioglu, 2011). Foreign supervisory board members (foreign external directors) should be treated in a similar manner to foreign CEOs. Generally, they are more independent in terms of their connections with the network of local contacts. External board members reflect the extent to which boards can retain their independence in monitoring issues related to financial reporting (Pathak \& Sun, 2013; Cho \& Rui, 2009). External independent directors are not familiar with local accounting and governance standards, which can hinder the process of supervision and assessments of business entities (Masulis et al., 2010). It can encourage the application of widely used and accepted standards, e.g. IFRS. Often, companies that have international stakeholders also have international supervisory boards, which require more standardized financial statements, e.g. IFRS (Pichler et al., 2018). Greater practical knowledge of IFRS among foreign board members increases their acceptance (Damak-Ayadi et al., 2020).Thus, it is hypothesized that:

H4: Supervisory boards composed of members from different countries are more likely to voluntarily adopt IFRS.

\section{CEO Nationality}

In big European entities, a CEO usually comes from the country where the company has its headquarters (Weber, 2010). They are often regarded to be highly educated business leaders. Foreign CEOs, then, can be regarded as independent decision-makers (Ruigrok et al., 2007). Foreign CEOs have even more independence than their counterparts who are outside members but come from the same country. In most cases, they are appointed as CEOs, but do not act as board chairpersons.

Chang and Sun (2009), Klai and Omri (2013) stress negative correlations between CEO duality and the likelihood of non-compliance with accounting standards and lower financial reporting quality. The positive impact of the company's most senior managers from abroad on reducing the scale of earnings management and accounting quality has also been confirmed by $\mathrm{Du}$ et al. (2017). Therefore, it can be assumed that foreign CEOs will make independent choices with regard to accounting standards and will improve accounting quality, or will even prefer the widely known standards to the local ones. Duan et al. (2019) noted, in turn, that CEO with experience acquired abroad rely more on models, solutions, global standards (e.g. IFRS) in relation to local practices. Thus, it is hypothesized that: IFRS.

H5: Foreign CEOs are more determined to adopt

\section{CEO's Academic Degree}

Education has a positive effect on disclosure quality in business entities (Reeb \& Zhao, 2013). On the other hand, academic knowledge about the diversity of accounting in individual countries prevails in theory rather than practice (Conesa \& Martinez, 2004). Bancel and Mittoo (2004) observed that the vast majority of CEOs in European listed companies have university degrees (above $70 \%$ ), whereas $40 \%$ hold MBA certificates. It cannot be expected that a large group of CEOs will have academic titles (Reeb \& Zhao, 2013; Graham et al., 2005). Adebayo and Sharma (2017) believe that the introduction of IFRS-related issues 
to academic curricula increases their acceptability in business practice. Lack of proper education, including academic education, hinders the introduction of IFRS (Siregar et al., 2017). It is hypothesized that:

H6: CEOs with academic degrees (PhD) are more likely to voluntarily adopt IFRS.

\section{CEO Gender}

Women are more cautious in making various financial decisions and are more likely to act in compliance with rules and regulations. Also, they are more compliant in taxreporting decisions than men (Barua et al., 2010). Musteen et al. (2006) investigated the acceptance of change among both male and female CEOs acting as managing directors. They found that women present a more liberal attitude to organisational changes than men do, when holding key positions in organisations. Ruigrok et al. (2007) stress that females who perform key functions in business entities are more independent. As compared with males, they less frequently hold simultaneous key positions in other businesses. Thus, they are likely to make more independent choices with regard to accounting standards. In general, women in managerial positions generally have a positive impact on accounting quality (Garcia-Sanchez et al., 2017). Hence they are more likely to be willing to introduce highquality accounting standards such as IFRS. Thus, it is hypothesized that:

H7: Entities managed by female CEOs are more likely to voluntarily adopt IFRS.

\section{CEO Age}

Age - to a significant extent - determines the acceptance of change in organisations (McClelland et al., 2010). It should be noted that senior managers are less likely to accept higher business risk with age (McClelland \& O'Brien, 2011). According to Lin et al (2014), age has an impact on the accepted level of risk. Senior managers are less inclined to take a risk and tend to make more conservative decisions. They are less interested in significant, difficult and time-consuming changes in financial reporting, such as the introduction of IFRS.

Huang et al. (2012) investigated the relationship between the quality of financial reporting and CEO age. The findings suggest that there is a positive correlation between the age of CEOs and the quality of financial reporting. On the other hand, older and long-serving employees may significantly influence their colleagues, to the detriment of financial reporting (Hunton et al., 2011). Davidson et al. (2007) note that people nearing retirement age may generate higher agency costs (the so-called horizon problem). CEO nearing retirement age may no longer cares about the accounting quality, being concerned with current rather than future gains. Thus, it is hypothesized that:

H8: With older CEOs, entities are less likely to voluntarily adopt IFRS.

\section{CEO Ownership}

On the basis of studies conducted in Western Europe it can be concluded that executive ownership usually does not exceed $5 \%$ of share capital (ca. $85 \%$ of cases), hence CEOs have relatively limited share ownership in listed companies, and in most cases they are minority shareholders (Bancel and Mittoo, 2004).

However, empirical research does not confirm a positive impact of CEO ownership on the quality of accounting (Yasser et al., 2017). According to Machuga and Teitel (2009), there is a negative correlation between earnings quality understood as income smoothing, timely loss recognition and conditional accruals and CEO ownership. When managers hold less than $25 \%$ of shares, managerial opportunism decreases. However, when ownership exceeds $25 \%$, managers are more likely to apply aggressive income-increasing discretionary accruals. Eng and Mak (2003) found that the low level of managerial ownership has a positive impact on increased disclosures. It should be noted that investors themselves do not find correlations between managerial ownership and earnings high predictive value (al-Dhamari \& Ismail, 2013). In view of the above, managers who own shares in the company do not support a higher accounting quality and they will also not be willing to apply the IFRS if their shareholding in the company will be significant. Thus,

H9: CEO with share ownership in the entity is less supportive of IFRS adoption.

\section{Material and Methods}

The study methodology involved a three-stage approach: (i) identification of variables that may influence the adoption of IFRS (ii) investigation of the correlation between identified variables (iii) estimation a logit model to assess the impact and significance of previously identified determinants on IFRS adoption.

The research focused on manufacturing companies under US SIC 1000 - US SIC 3999 classification. According to other studies, the production sector applies IFRS more frequently than other industries (Wu \& Zhang, 2009). This sector is characterised by higher debt levels, so production companies may need IFRS to monitor agency conflicts between investors and lenders (Dumontier \& Raffournier, 1998). Companies from this sector have more freedom in implementing independent financial policies than financial or service businesses. The production sector is characterised by similar core operational activities, production cycles as well as similar financial categories (Kedzior, 2012). Production is the largest sector in Poland in terms of the number of businesses, hence the results of the analysis can apply to all Polish business entities.

We examined the companies listed in the Polish market in 2016. The analysis covered 445 companies, $61 \%$ of the total. The data was collected from the Orbis database and companies websites.

Company size, presence of international investor, supervisory board characteristics and CEO characteristics were considered as the possible factors that may influence adoption of IFRS. Company size is measured by operating revenues (Euro); this variable is defined in a similar way by Andre et al. (2012), and Bessieux-Ollier and Walliser (2012). Supervisory board characteristics was analysed in terms of presence of international board and size. A similar approach to measure the supervisory board in terms of nationality was presented by Masulis et al. (2010); Klai and 
Omri (2013). Supervisory board size - was measured as the number of board members. The identical approach was presented by Chiraz and Anis (2012), Vafeas, 2000; Karagul and Yonet (2012). CEO was analysed in terms of nationality, education, gender, age, share ownership. CEO nationality was analysed in terms of the country of origin of the entity and academic degree in terms of holding a $\mathrm{PhD}$ degree. A similar approach was adopted by Anderson et al., 2004; Bradbury et al. (2006); Karagul and Yonet (2012).

The correlation between the identified variables was estimated. Following that, a logit model was specified and estimated in order to assess the impact and significance of identified determinants on IFRS adoption. The logit model was used by a number of authors in similar research studies: Andre et al. (2012); Bessieux-Ollier and Walliser (2012); Bassemir (2018); Dumontier and Raffournier (1998), and Wu and Zhang (2009).

The model is specified as follows:

logit (Probability of IFRS $)=\beta 0+\beta 1$ (Company size)

$+\beta 2$ (International investors) $+\beta 3$ (Supervisory board size) $+\beta 4$ (International supervisory board) $+\beta 5(C E O$ nationality $)+\beta 6(C E O$ academic degree $)+\beta 7(C E O$ gender $)+\beta 8(C E O$ age $)+\beta 9($ CEO ownership $)+e$

Data is shown with means, standard deviations, medians and interquartile ranges, differences were calculated with Mann-Whitney test and Wilocoxon signedrank test. A p-value of less than 0.05 was considered statistically significant. We used STATISTICA, Statsoft (2011), version 13.3.

\section{Results}

Across the firms in our sample (445) the average operating revenues is $8,579,000 €$ (table 1 ). Moreover, 38,65\% of the sample firms have operating revenues lower than $1,000,000$ $€$ and $20,45 \%$ higher than $10,000,000 €$. The number of persons in supervisory board is on average 2.57 and in 79,55 $\%$ of the sample firms is less than 4 persons.

\section{Descriptive Statistics of the Sample Firms}

\begin{tabular}{|c|c|c|}
\hline \multicolumn{2}{|c|}{ Variables } & Mean (SD); Median [Q1 - Q3] \\
\hline Company size (thousand $€$ ) & COMPS & $8,579(31,826) ; 1,346[345 ; 5,019]$ \\
\hline Supervisory board size (person) & SUPBOS & $2.57(2.66) ; 1.00[1.00 ; 3.00]$ \\
\hline CEO age (years) & CEOA & $52.0(13.3) ; 53.0[42.0 ; 63.0]$ \\
\hline & & $\mathrm{n}(\%)$ \\
\hline Company size (thousand $€$ ) & COMPSR & \\
\hline$<1,000$ & & $172(38,65)$ \\
\hline $1,000-10,000$ & & $180(40,45)$ \\
\hline$>10,000$ & & $91(20,45)$ \\
\hline CEO age (years) & CEOAG & \\
\hline$<40$ & & $98(20,02)$ \\
\hline $41-60$ & & $219(49,21)$ \\
\hline$>60$ & & $128(28,76)$ \\
\hline Board size (person) & SUPBOSR & \\
\hline$<4$ & & $172(38,65)$ \\
\hline $4-10$ & & $65(14,61)$ \\
\hline$>10$ & & $23(5,84)$ \\
\hline International investor & ININW & \\
\hline No & & $311(84.50)$ \\
\hline Yes & & $57(15.50)$ \\
\hline International supervisory board & INTSUP & \\
\hline No & & $335(91.0)$ \\
\hline Yes & & $33(8.97)$ \\
\hline CEO nationality & CEON & \\
\hline national & & $358(97.3)$ \\
\hline foreign & & $10(2.72)$ \\
\hline CEO academic degree & CEOAD & \\
\hline Without Ph.D. & & $356(96.70)$ \\
\hline With Ph. D. & & $12(3.26)$ \\
\hline CEO gender & CEOG & \\
\hline Male & & $336(91.30)$ \\
\hline Female & & $32(8.70)$ \\
\hline CEO ownership & CEOWN & \\
\hline not shareholder & & $227(61.70)$ \\
\hline shareholder & & $141(38.30)$ \\
\hline
\end{tabular}

COMPS = company size COMPSR = company size $($ ranges $) ; C E O A G=C E O$ age $;$ SUPBOS = Board size; SUPBOSR = Board size $($ ranges $) ; I N I N W=$ International investor; INTSUP = International supervisory board; CEON = CEO nationality;

$C E O A D=C E O$ academic degree $; C E O G=C E O$ gender $; C E O W N=C E O$ ownership

Source: own research

CEOs have an average age of 52 years, and almost $50 \%$ of them is 41-60 years old. There are no international investors and international supervisory board in $84.50 \%$ and $91 \%$ of the sample firms, respectively. The statistics show that $97.30 \%$ CEOs are Polish and $3.26 \%$ of CEOs have a $\mathrm{PhD}$. The findings reveal that female CEOs lead only 32 of the sample firms $(8.70 \%)$. In 141 companies, CEO holds the firm's shares.

Our study revealed that IFRS adopted 77 companies $(17,30 \%)$ (table 2$)$. Firms, which adopt IFRS voluntarily are 
bigger than entities applying local accounting standards. We found statistically significant differences between companies that confirmed (IFRS) and not confirmed IFRS adoption in terms of supervisory board size, international investor presence, international supervisory board and CEO nationality. In companies that adopted IFRS the supervisory presence of international investor. board is thrice as big as in nIFRS companies. The average number of people in IFRS companies' supervisory board has on average 6,30 members, while in nIFRS companies 2,57. In almost $40 \%$ of IFRS companies and in $15 \%$ of nIFRS ones we observed the

Table 2

Variable Comparison Companies that Confirmed (IFRS) and Not Confirmed (nIFRS) International Financial Reporting Standards Adoption

\begin{tabular}{|c|c|c|c|}
\hline Variables & $\begin{array}{c}\text { nIFRS } \\
(n=368)\end{array}$ & $\begin{array}{c}\text { IFRS } \\
(\mathbf{n}=77)\end{array}$ & p-value* \\
\hline & \multicolumn{2}{|c|}{$\begin{array}{c}\text { Mean (SD) } \\
\text { Median [Q1 - Q3] }\end{array}$} & \\
\hline \multirow{2}{*}{ Company size (thousand $€$ ) } & $8,579(31,826)$ & $169,900(581,151)$ & \multirow[b]{2}{*}{$<0.001 * *$} \\
\hline & $1,346[345 ; 5,019]$ & $7,054[2452 ; 35,360]$ & \\
\hline \multirow{2}{*}{ Supervisory board size (person) } & $2.57(2.66)$ & $6.30(10.4)$ & \multirow{2}{*}{$0.001 * *$} \\
\hline & $1.00[1.00 ; 3.00]$ & $2.00[1.00 ; 8.00]$ & \\
\hline \multirow{3}{*}{ CEO age (years) } & $52.0(13.3)$ & $50.2(12.6)$ & \multirow{3}{*}{ NS } \\
\hline & $53.0[42.0 ; 63.0]$ & $52.0[41.0 ; 60.0]$ & \\
\hline & n $(\%)$ & n $(\%)$ & \\
\hline \multicolumn{4}{|l|}{ Company size - range (thousand $€$ ) } \\
\hline$<1000$ & $160(43,48)$ & $12(15,58)$ & \multirow{3}{*}{$<0,001^{*}$} \\
\hline $1000-10000$ & $151(41,03)$ & $29(37,66)$ & \\
\hline$>10000$ & $57(15,49)$ & $36(46,75)$ & \\
\hline \multicolumn{4}{|l|}{ CEO age - range (years) } \\
\hline$<40$ & $82(22,28)$ & $16(20,78)$ & \multirow{3}{*}{ NS } \\
\hline $41-60$ & $177(48,10)$ & $42(54,54)$ & \\
\hline$>60$ & $109(29,62)$ & $19(24,67)$ & \\
\hline \multicolumn{4}{|l|}{ Board size - range (person) } \\
\hline$<4$ & $305(82,88)$ & $49(63,64)$ & \multirow{3}{*}{$0,004 *$} \\
\hline $4-10$ & $50(13,59)$ & $15(19,48)$ & \\
\hline$>10$ & $13(3,53)$ & $13(16,88)$ & \\
\hline \multicolumn{4}{|l|}{ International investor } \\
\hline No & $311(84.50)$ & $47(61.00)$ & \multirow{2}{*}{$<0.001^{*}$} \\
\hline Yes & $57(15.50)$ & $30(39.00)$ & \\
\hline \multicolumn{4}{|l|}{ International supervisory board } \\
\hline No & $335(91.00)$ & $61(79.20)$ & \multirow{2}{*}{$0.005 *$} \\
\hline Yes & $33(8.97)$ & $16(20.80)$ & \\
\hline \multicolumn{4}{|l|}{ CEO nationality } \\
\hline national & $358(97.30)$ & $67(87.00)$ & \multirow{2}{*}{$0.001 *$} \\
\hline foreign & $10(2.72)$ & $10(13.00)$ & \\
\hline \multicolumn{4}{|l|}{ CEO academic degree } \\
\hline Without Ph.D. & $356(96.70)$ & $75(97.40)$ & \multirow[t]{2}{*}{ NS } \\
\hline With Ph. D. & $12(3.26)$ & $2(2.60)$ & \\
\hline \multicolumn{4}{|l|}{ CEO gender } \\
\hline Male & $336(91.30)$ & $71(92.20)$ & \multirow[t]{2}{*}{ NS } \\
\hline Female & $32(8.70)$ & $6(7.79)$ & \\
\hline \multicolumn{4}{|l|}{ CEO ownership } \\
\hline not shareholder & $227(61.70)$ & $53(68.80)$ & \multirow{2}{*}{ NS } \\
\hline shareholder & $141(38.30)$ & $24(31.20)$ & \\
\hline
\end{tabular}

* Statistical significance calculated with Mann-Whitney test.

** Statistical significance calculated with Pearson's $\chi^{2}$

Source: own research

The International supervisory board was found twice more often in IFRS companies than in the others. Before employing the regression estimation, we investigated the correlation between independent variables. Table 3 presents correlations between the analysed variables.

A positive impact of company size and supervisory board on voluntary IFRS adoption is confirmed with the impact of company size being more significant. As expected, there is a positive correlation between company size and supervisory board size.

In conclusion, it can be legitimately assumed that significant factors include: international investor, CEO nationality, international supervisory board, company size, and supervisory board size.
To analyze the factors affecting voluntary IFRS adoption we used the binary logit regression model. The dependent variable (IFRS adoption) is a binary variable assuming the value 1 (IFRS company) or zero (nIFRS company). The logit model, which is based on cumulative logistic probability functions, is computationally easier to use and has the advantage to predict the probability of IFRS adoption in company. The results are presented in Table 4. A positive impact of company size and presence of international investor on voluntary IFRS adoption is confirmed by the results. Our study did not validate the impact of CEO characteristics and supervisory board influence on voluntary IFRS adoption. 
Spearman Correlations Coefficient between Independent Variables

\begin{tabular}{|c|c|c|c|c|c|c|c|c|c|}
\hline Variable & COMPS & ININW & SUPBOS & INTSUP & CEON & CEOAD & CEOG & CEOAG & CEOWN \\
\hline COMPS & 1 & & & & & & & & \\
\hline ININW & $0,2308^{*}$ & 1 & & & & & & & \\
\hline SUPBOS & $0,5981^{*}$ & $0,3192^{*}$ & 1 & & & & & & \\
\hline INTSUP & $0,3342^{*}$ & $0,3153^{*}$ & $0,4903^{*}$ & 1 & & & & & \\
\hline CEON & $0,4861^{*}$ & $0,3033^{*}$ & $0,5315^{*}$ & $0,5820^{*}$ & 1 & & & & \\
\hline CEOAD & 0,0680 & 0,0734 & $0,1559^{*}$ & $0,1422^{*}$ & $0,2716^{*}$ & 1 & & & \\
\hline CEOG & $-0,038$ & 0,0012 & $-0,0239$ & $-0,0047$ & $-0,0663$ & $-0,0550$ & 1 & & \\
\hline CEOAG & $-0,0946^{* *}$ & 0,0160 & $-0,0344$ & $-0,0121$ & $-0,0359$ & $-0,0004$ & 0,0160 & 1 & \\
\hline CEOWN & $-0,093^{* *}$ & $-0,0214^{*}$ & $-0,1779^{*}$ & $-0,1801^{*}$ & $-0,1665^{*}$ & $-0,0850^{* * *}$ & $-0,0514$ & $-0,0492$ & 1 \\
\hline IFRS & $0,2446^{*}$ & $0,2239^{*}$ & $0,2756^{*}$ & $0,1427^{*}$ & $0,1875^{*}$ & $-0,0144$ & $-0,0122$ & $-0,0500$ & $-0,0556$ \\
\hline
\end{tabular}

COMPS = company size; $C E O A G=C E O$ age $;$ SUPBOSR = Board size; ININW = International investor; INTSUP = International supervisory board; $C E O N=C E O$ nationality; $C E O A D=C E O$ academic degree; $C E O G=C E O$ gender; $C E O W N=C E O$ ownership; $p$-values in brackets; ${ }^{*}-$ significant at the 0.01 level; ${ }^{* *}$ - significant at the 0.05 level.

Source: own research

\section{Logistic Regression Estimation Results for IFRS Adoption}

Table 4

\begin{tabular}{|c|c|c|c|}
\hline & Coefficient estimate & Standard error of coefficient estimate & $p$-value \\
\hline Intercept & 2.2817 & 0.9257 & 0.0137 \\
\hline COMPS & -0.0000 & 0.0000 & $0.0351 *$ \\
\hline ININW & 0.4347 & 0.1645 & $0.0082 * *$ \\
\hline INTSUP & -0.0718 & 0.0489 & 0.1423 \\
\hline INTSUP & -0.3220 & 0.2903 & 0.2674 \\
\hline CEON & -0.1814 & 0.5133 & 0.7236 \\
\hline CEOAD & -0.5482 & 0.5647 & 0.3316 \\
\hline CEOG & 0.0056 & 0.2398 & 0.9813 \\
\hline CEOAG & 0.0084 & 0.0103 & 0.4150 \\
\hline CEOWN & 0.0431 & 0.1469 & 0.7690 \\
\hline
\end{tabular}

*** - significant at the 0.1, 0.01 levels, respectively; $C O M P S=$ company size; CEOAG =CEO age; SUPBOSR = Board size; ININW = International investor; INTSUP = International supervisory board; $C E O N=C E O$ nationality; $C E O A D=C E O$ academic degree $; C E O G=C E O$ gender CEOWN = CEO ownership;

Source: own research

\section{Discussion}

Our study revealed that bigger companies more often adopt IFRS. The relationship between a company's size and IFRS adoption was confirmed by Andre et al. (2012), Wu and Zhang (2009) and Tran et.al. (2019). We presume this is because large businesses frequently rely on external financing in foreign markets, and IFRS adoption can reduce the cost of capital. IFRS, unlike various local accounting standards, facilitate adoption of many alternative solutions, which can be employed by large and operationally and geographically diversified entities. Large companies are equipped with necessary financial experts and resources, enabling them to adopt IFRS (Andre et al., 2012). Also, they incur lower information production costs and lower costs of competitive disadvantage associated with disclosures. They are inclined to disclose more information, which does not pose the threat of losing competitive advantage. As a result, bigger companies are able to meet stricter requirements imposed by
IFRS (Bessieux-Ollier \& Walliser, 2012). IFRS adoption in large companies can be also positively evaluated by markets as an additional indication of a corporate governance system. Moreover, large companies' reliability and transparency are, frequently conditioned by IFRS adoption.

We confirmed the results presented by Covrig et al. (2007), who discovered statistically significant impact of foreign investors on voluntary IFRS adoption. Their study claimed that international investors select targets with which they are well acquainted, and give preference to companies with effective corporate governance systems, which implies high quality accounting systems. We presume that international investors have sufficient financial, human and organizational resources to make the right decisions with regard to the quality of accounting standards (Gul et al., 2010). On the other hand, DeFond et. al. (2019) emphasize that foreign investors' home country institutions affect their reaction to IFRS adoption or other activities. For example foreign investors from countries with weak legal and 
economic institutions, similar to those in China, are supposed to reduce their investment by a greater amount than foreign investors from countries with strong institutions, like Poland (Popov, 2001).

A high proportion of supervisory board members in companies from Poland come from the company's country of origin. International supervisory boards still constitute a relatively insignificant group also in West European corporations (van Veen \& Marsman, 2008). It can be assumed that the number of members in international supervisory boards in Polish companies will increase due to the economic development of individual countries or companies as well as intensified international trade. As foreign supervisory boards have a positive impact on the quality of accounting in emerging markets, we presume that replacement of local standards with IFRS in less developed markets improves the quality of accounting (Klai \& Omri, 2013; Firth et al., 2007; An \& Naughton, 2007).

The size of a supervisory board is only partially statistically significant determinant of voluntary IFRS adoption. The results are somewhat surprising because the size of a supervisory board usually leads to improved transparency of financial information (Upadhyay \& Sriram, 2011). Larger boards in big entities need comprehensive and high quality information to perform their supervisory functions, hence the likelihood of application of IFRS should be higher. On the other hand, it must be kept in mind that board size is commonly determined by national law or listing requirements and is mostly based on the enterprise size and sector (Bezo et al., 2015).

Our study verified positively the hypothesis claiming the impact of international supervisory boards on IFRS adoption, but statistical significance is low. However, to some extent international supervisory boards may be associated with the expansion of international business activity, which leads to broader IFRS application (Andre $e t$ al., 2012). It will be necessary to develop a business language understandable to all supervisory board members (Palmer \& Varner, 2007). Foreign board members can enforce IFRS application - they are better acquainted with international standards. Frequently, as the representatives of foreign investors, they require adoption of accounting standards applied by parent companies. It seems that the impact of this factor on IFRS adoption - to be more significant - should be enhanced by other conditions.

We found that a CEO's nationality determines voluntary IFRS adoption, but only in small extent. The results seem surprising because foreign CEOs, similarly to foreign supervisory board members, usually have more confidence in generally accepted accounting standards (IFRS). It should be noted that the majority of CEOs in the companies come from their countries of origin. This phenomenon is typical of relatively small entities, with their business activity located chiefly in their country of origin. The confirmation of this phenomenon can be found in Weber's (2010) research. Indeed, foreign CEOs are significantly more numerous in companies adopting IFRS as compared with businesses applying local standards. They usually perform managerial, not supervisory functions. CEO positions are frequently held by business leaders who have broad practical knowledge (Ruigrok et al., 2007). They are more aware of the possible benefits resulting from IFRS application. People from other countries, who have international professional experience, are more aware of the positive impact of IFRS on the quality of accounting. Foreign CEOs are more likely to favour world and high quality accounting standards (IFRS) than CEOs operating in local markets. Possibly, foreign executives from less developed markets, who lack broad international experience, do not guarantee IFRS application.

A CEO's academic degree does not turn out to be statistically significant. It seems surprising in light of the fact that literatures attribute much significance to academic education as a determinant of IFRS application (Sucher \& Jindrichovska, 2004). It should be highlighted that it is not common for CEOs in Europe to have academic degrees. CEOs are much more interested in obtaining MBA degrees than academic titles (Bancel \& Mittoo, 2004).

Our study did not confirm the significant influence of gender on IFRS adoption. We found out that in companies with male CEOs the extent of IFRS adoption was the same as in companies with female CEOs. We did not confirm the Musteen et al., (2006) and Davis et al. (2010) findings, who discovered higher acceptance of change among female CEOs (for example IFRS adoption). We suppose that this maybe because females performing key accounting functions adopt more conservative financial reporting policies. This was confirmed with empirical studies conducted by Francis et al. (2009) who found that females in key positions, responsible for accounting, are more likely to present financial results on the basis of conservative assessments. This is especially the case for CEE countries, because local accounting standards in these countries are more conservative than IFRS.

Age was not found to be a statistical significant determinant of voluntary IFRS application. CEO average age for businesses applying local standards is slightly higher. Most CEOs are between the ages 30 and 70 years. The literature do not explicitly confirm correlations between age and choices of financial reporting systems. Younger CEOs are inexperienced in business but more likely to accept change and risk (for example IFRS adoption) (McClelland \& O'Brien, 2011). This is of key importance for relatively small entities, which prepare non-consolidated financial statements, develop faster, demonstrate higher business risk, and need a dynamic and bold leadership (McClelland and O'Brien, 2011; McClelland et al., 2010). It should be noted that a large number of empirical studies confirm a negative impact of CEO age on the quality of accounting (Srinivasan, 2005; Francis et al., 2008). We presume that it is because people nearing retirement age are not inclined to take a risk and focus on short-term gains, frequently to the detriment of long-term profitability and thus the probability that older CEOs introduce IFRS will be lower. The original enthusiasm, acceptance of risk and openness to new trends (IFRS) can be gradually replaced: unwillingness to take a risk and accept change, and the desire to retain status quo (local accounting standards). Experience and expertise gained in the process of continuous learning confirm the benefits of international standards and lead to IFRS application. It might be assumed that middle-aged CEOs are more likely to adopt IFRS, while the youngest and oldest CEOs are less inclined to apply IFRS for the above stated reasons. We suppose that the 
uneven impact of age on IFRS adoption may be due to the difference in the labor market (e.g. the level of job rotation, wages). For example the longer an employee is hired at his/her job, his/her ability to taking extra effort at work decreases over time. Rotating the employee to a different job may generate a fresh impulse for effort. However, job rotation also reduces the employee's time horizon, thus reducing propensity to implement long-term projects, like IFRS adoption (Hakenes \& Katolnik, 2017).

CEO ownership is not a clear determinant of IFRS adoption, either. CEOs in the analysed companies may not be fully aware of the numerous benefits of IFRS, being discouraged by the high costs and complexity of IFRS adoption. Voulgaris et al. (2013) claim that given the fair value measurement, IFRS adoption could result in the volatility of balance sheet items. Therefore, IFRS can hinder measurement of managers' performance according to accounting data. We presume that lack of influence of CEO ownership on IFRS adoption maybe associated with CEO ownership structure rather than fact the CEO is a shareholder (Banbhan et al., 2018).

\section{Conclusions}

The paper analyzed the influence of various CEO and supervisory board characteristics on voluntary IFRS adoption in listed companies preparing unconsolidated financial statements from Poland. It contributes in identifying the major determinants of voluntary IFRS adoption, such as company size and international investors presence. We discovered that the size of supervisory boards, the presence of international members in those boards, and supervisory board size have a positive impact on IFRS adoption. The influence of CEO's gender and age, and CEO ownership were not found to be statistically significant determinants. We conclude that voluntary IFRS adoption depends on the characteristics of supervisory boards, rather than the individual features of CEOs. This should not seem surprising, given a supervisory board's responsibility for corporate governance good practices, including the choice of accounting standards. The greatest probability of voluntary IFRS adoption is conditioned by the cooccurrence of specific variables: international investor and CEO nationality; board size and international board; board size, international board and CEO gender; CEO age and international investor.

The study contributes to the literature by shedding further light into the new variables determining voluntary IFRS adoption in Polish companies. To the author's best knowledge, no previous research papers referred to the discussed CEO and supervisory board characteristics as drivers of voluntary IFRS adoption. All the determinants which can be regarded as the international components of corporate governance systems (international investor and CEO nationality; board size and international board) are verified as statistically significant.

Our findings can be useful for regulators as well as various users of financial statements prepared by listed companies. The findings are also significant in the context of voluntary IFRS adoption by publicly traded companies which do not apply IFRS, or by unlisted businesses. This finding adds to the literature, which suggests a capital market benefit to mandatory IFRS adoption in countries with weak standard enforcement infrastructure. We illustrate that IFRS adoption can improve the information environment of firms as they have the economic incentive to achieve higher levels of compliance.

\section{Limitation of the Study}

The paper did not analyse more variables due to data limitations. This problem relates mainly to the NewConnect market in Poland, created for smaller companies, which do not have to meet strict disclosure requirements. Future studies could complement the results of voluntary IFRS adoption analysis for East European countries by comparing them with those focusing on West European companies, including more variables such as: presence of independent managers, proportion of supervisory board members to management board members, and CEO duality.

\section{References}

Abbadi, S. S., Hijazi, Q. F., \& Al-Rahahleh, A. S. (2016). Corporate governance quality and earnings management: Evidence from Jordan. Australasian Accounting, Business and Finance Journal, 10(2), 54-75. http://dx.doi.org/10. 14453/aabfj.v10i2.4

Adebayo, A., \& Sharma, H. (2017). Analysis of Implementation Experiences of IFRS in Nigeria. Copyright 2017 by Institute for Global Business Research, Nashville, TN, USA, 148.

al-Dhamari, R. A., \& Ismail, K. N. I. K. (2013). Governance Structure, Ownership Structure and Earnings Predictability: Malaysian Evidence. Asian Academy of Management Journal of Accounting and Finance, 9(1), 1-23.

An, Y., \& Naughton, T. (2007). Does Foreign Ownership Increase Financial Reporting Conservatism. Melbourne: RMIT University.

Anderson, R. C., Mansi, S. A., \& Reeb, D. M. (2004). Board Characteristics, Accounting Report Integrity, and the Cost of Debt. Journal of accounting and economics, 37(3), 315-342. https://doi.org/10.1016/j.jacceco. 2004.01.004

Andre, P., Walton, P. J., \& Yang, D. (2012). Voluntary Adoption of IFRS: A Study of Determinants for UK Unlisted Firms, ESSEC KPMG Financial Reporting Centre, 3 January. https://doi.org/10.2139/ssrn.1978986 
Marcin Kedzior, Małgorzata Cyganska, Dimitrios Syrrakos. Determinants of Voluntary International Financial Reporting...

Arsen, D., Grace, G., Sarikas, R. H. S., \& Senteney, D. L. (2010). An Investigation of the Comparative Impact of Degree of Implementation of IFRS upon the Public and Private Information Quality of Asia Pacific Country Firms. The International Business \& Economics Research Journal, 9(3), 27-45. https://doi.org/10.19030/iber.v9i3.534

Astami, E. W., \& Tower, G. (2006). Accounting-policy Choice and Firm Characteristics in the Asia Pacific Region: An International Empirical Test of Costly Contracting Theory. The international journal of accounting, 41(1), 1-21. https://doi.org/10.1016/j.intacc.2005.12.004

Baluch, C., Cohen, R., Soto, H., Tucker, P., Volkan, A., \& Wright G. (2011). Fair Value Accounting: Current Status and a Proposal for Convergence. The International Business \& Economics Research Journal, 4(10). https://doi.org/10. 19030/iber.v10i4.4180

Banbhan, A., Cheng, X., \& Ud Din, N. (2018). Financially qualified members in an upper echelon and their relationship with corporate sustainability: Evidence from an emerging economy. Sustainability, 10(12), 4697. https://doi.org/10. $3390 /$ su10124697

Bancel, F., \& Mittoo, U. R. (2004). Cross-Country Determinants of Capital Structure Choice: A Survey of European Firms. Financial Management, 33(4), 102-132.

Barth, M., \& Taylor, D. (2010). In Defense of Fair Value: Weighing the Evidence on Earnings Management and Asset Securitizations. Journal of Accounting and Economics, 49(1/2), 6-33. https://doi.org/10.1016/j.jacceco.2009.10.001

Barua, A., Davidson, L. F., Rama, D. V., \& Thiruvadi, S. (2010). CFO Gender and Accruals Quality. Accounting Horizons, 24(1), 25-39. https://doi.org/10.2308/acch.2010.24.1.25

Bassemir, M., \& Novotny-Farkas, Z. (2018). IFRS adoption, reporting incentives and financial reporting quality in private firms. Journal of Business Finance \& Accounting, 45 (7/8), 759-796. https://doi.org/10.1111/jbfa.12315

Bassemir, M. (2018). Why Do Private Firms Adopt IFRS?. Accounting and Business Research, 48 (3), $237-263$. https://doi.org/10.1080/00014788.2017.1357459

Bessieux-Ollier, C., \& Walliser, E. (2012). Why Firms Listed on an Unregulated Financial Market Comply Voluntarily with IFRS: An Empirical Analysis with French Data, Montpellier Research in Management.

Bezo, Y., Brahimi, A. D. D. F., \& Dibra, R. (2015). Corporate Governance in Transition Countries. Corporate Governance, $6(4)$.

Borowski, Sz., \& Kariozen, M. (2007). Application of International Financial Reporting Standards in Polish Listed Companies. The Impact on Hedge Accounting and Consolidation. Theoretical Journal of Accounting, 38, 5-24.

Bouchareb, M., Ajina, A., \& Souid, S. (2014). Does the Adoption of IAS/IFRS with a Strong Governance Mechanism Can Deter Earnings Management?. International Journal of Academic Research in Economics and Management Sciences, 3(1). https://doi.org/10.6007/IJAREMS/v3-i1/645

Bova, F. (2007). The Determinants and Consequences of Higher Accounting Quality Following IFRS Adoption in Emerging Markets: Inferences from Kenya. Yale School of Management, December, 1-34.

Bradbury, M., Mak, Y. T., \& Tan, S. M. (2006). Board Characteristics, Audit Committee Characteristics and Abnormal Accruals. Pacific Accounting Review, 18(2), 47-68. https://doi.org/10.1108/01140580610732813

Broberg, P., Tagesson, T., \& Collin, S. O. (2010). What Explains Variation in Voluntary Disclosure? A Study of the Annual Reports of Corporations Listed on the Stockholm Stock Exchange. Journal of Management \& Governance, 14(4), 351-377. https://doi.org/10.1007/s10997-009-9104-y

Chang, J. C., \& Sun, H. L. (2009). Crossed-listed Foreign Firms' Earnings Informativeness, Earnings Management and Disclosures of Corporate Governance Information under SOX. The International Journal of Accounting, 44(1), 1-32. https://doi.org/10.1016/j.intacc.2008.12.004

Chiraz, D., \& Anis, J. (2012). Corporate Governance, Mandatory Adoption of IAS/IFRS and Earnings Management by French IPO Companies. International Journal of Management and Strategy, 3(5).

Cho, S., \& Rui, O. M. (2009). Exploring the Effects of China's Two-tier Board System and Ownership Structure on Firm Performance and Earnings Informativeness. Asia-Pacific Journal of Accounting \& Economics, 16(1), 95-117. https://doi.org/10.1080/16081625.2009.9720831

Choi, F. D. S., \& Meek, G. K. (2005). International Accounting, Pearson Prentice Hall, New Jersey.

Collier, P., \& Zaman, M. (2005). Convergence in European Corporate Governance: the Audit Committee Concept. Corporate Governance: An International Review, 13(6), 753-768. https://doi.org/10.1111/j.1467-8683.2005.00468.x

Conesa, I. M., \& Martinez, E. O. (2004). International Financial Analysis and Handicap of Accounting Diversity. European Business Review, 16(3), 272-291. https://doi.org/10.1108/09555340410536217 
Covrig, V. M., Defond, M. L., \& Hung, M. (2007). Home Bias, Foreign Mutual Fund Holdings, and the Voluntary Adoption of International Accounting Standards. Journal of Accounting Research, 45(1), 41-70. https://doi.org/10.1111/j.1475679X.2007.00226.X

Damak-Ayadi, S., Sassi, N., \& Bahri, M. (2020). Cross-country determinants of IFRS for SMEs adoption, Journal of Financial Reporting and Accounting, Vol. ahead-of-print No. ahead-of-print. https://doi.org/10.1108/JFRA-12-20180118

Davarcioglu, T. (2011). Empirical Accounting Research. Thesis (PhD), Humboldt-Universitat Berlin.

Davidson III, W. N., Xie, B., Xu, W., \& Ning, Y. (2007). The Influence of Executive age, Career Horizon and Incentives on Pre-Turnover Earnings Management. Journal of Management \& Governance, 11(1), 45-60. https://doi.org/10. 1007/s10997-007-9015-8

Davis, P. S., Babakus, E., Danskin Englis, P., \& Pett, T. (2010). The Influence of CEO Gender on Market Orientation and Performance in Service Small and Medium-Sized Service Businesses. Journal of Small Business Management, 48(4), 475-496. https://doi.org/10.1111/j.1540-627X.2010.00305.x

DeFond, M., Gao, X., Li, O. Z., \& Xia, L. (2019). IFRS adoption in China and foreign institutional investments. China Journal of Accounting Research, 12(1), 1-32. https://doi.org/10.1016/j.cjar.2018.07.006

Du, X., Jian, W., \& Lai, S. (2017). Do foreign directors mitigate earnings management? Evidence from China. The International Journal of Accounting, 52(2), 142-177. https://doi.org/10.1016/j.intacc.2017.04.002

Duan, T., Hou, W., \& Rees, W. (2019). CEO international experience and foreign IPOs, Economic Modelling, December. https://doi.org/10.1016/j.econmod.2019.11.033

Dumontier, P., \& Raffournier, B. (1998). Why Firms Comply Voluntarily with IAS: an Empirical Analysis with Swiss Data. Journal of International Financial Management \& Accounting, 9(3), 216-245. https://doi.org/10.1111/1467646X.00038

Eng, L. L., \& Mak, Y. T. (2003). Corporate Governance and Voluntary Disclosure. Journal of Accounting and Public Policy, 22(4), 325-345. https://doi.org/10.1016/S0278-4254(03)00037-1

Firth, M., Fung, P. M,. \& Rui, O. M. (2007). Ownership, Two-Tier Board Structure, and the Informativeness of EarningsEvidence from China. Journal of accounting and public policy, 26(4), 463-496. https://doi.org/10.1016/j.jaccpubpol. 2007.05.004

Francis, B., Hasan, I., Park, J. C., \& Wu, Q. (2009). Gender Differences in Financial Reporting Decision-Making: Evidence from Accounting Conservatism. FMA Annual Meeting, October, 21-24. https://doi.org/10.1111/1911-3846.12098

Francis, J. R., Khurana, I. K., Martin, X., \& Pereira, R. (2008a.) The Role of Firm-Specific Incentives and Country Factors in Explaining Voluntary IAS adoptions: Evidence from Private Firms. European accounting review, 17(2), 331-360. https://doi.org/10.1080/09638180701819899

Francis, J., Huang, A. H., Rajgopal, S., \& Zang, A. Y. (2008). CEO Reputation and Earnings Quality. Contemporary Accounting Research, 25(1), 109-147. https://doi.org/10.1506/car.25.1.4

Garcia-Sanchez, I. M., Martínez-Ferrero, J., \& García-Meca, E. (2017). Gender diversity, financial expertise and its effects on accounting quality. Management Decision, 55 (2), 347-382. https://doi.org/10.1108/MD-02-2016-0090

Graham, A., Nandialath, A. M., Skaradzinski, D., \& Rustambekov, E. (2017). Macroeconomic Determinants of International Financial Reporting Standards (IFRS) Adoption: Evidence from the Middle East North Africa (MENA) Region. Revista Internacional Administracion \& Finanzas, 9(1), 39-48.

Graham, J. R., Harvey, C. R., \& Rajgopal, S. (2005). The Economic Implications of Corporate Financial Reporting. Journal of accounting and economics, 40(1), 3-73. https://doi.org/10.1016/j.jacceco.2005.01.002

Gul, F. A., \& Leung, S. (2004). Board Leadership, Outside Directors' Expertise and Voluntary Corporate Disclosures. Journal of Accounting and public Policy, 23(5), 351-379. https://doi.org/10.1016/j.jaccpubpol.2004.07.001

Gul, F. A., Kim, J. B., \& Qiu, A. A. (2010). Ownership Concentration, Foreign Shareholding, Audit Quality, and Stock Price Synchronicity: Evidence from China. Journal of Financial Economics, 95(3), 425-442. https://doi.org/10.1016/j. jfineco.2009.11.005

Hakenes, H., \& Katolnik, S. (2017). On the incentive effects of job rotation. European Economic Review, 98, 424-441. https://doi.org/10.1016/j.euroecorev.2017.07.003

Ho, J. A. (2009). Association between Board Characteristics and Accounting Conservatism: Empirical Evidence from Malaysia. Thesis (PhD), Auckland University of Technology. 
Marcin Kedzior, Małgorzata Cyganska, Dimitrios Syrrakos. Determinants of Voluntary International Financial Reporting...

Ho, S. S. M., \& Wong, K. S. (2001). A Study of the Relationship Between Corporate Governance Structures and the Extent of Voluntary Disclosure. Journal of International Accounting, Auditing \& Taxation, 10, 139-156. https://doi.org/10. 1016/S1061-9518(01)00041-6

Hope, O. K., Jin, J., \& Kang, T. (2006). Empirical Evidence on Jurisdictions that Adopt IFRS. Journal of International Accounting Research, 5(2), 1-20. https://doi.org/10.2308/jiar.2006.5.2.1

Hope, O. K., Langli, J. C., \& Thomas, W. B. (2012). Agency Conflicts and Auditing in Private Firms, Accounting. Organizations and Society, 37(7), 500-517. https://doi.org/10.1016/j.aos.2012.06.002

Houqe, M. N., Monem, R. M., \& van Zijl, T. (2016). The economic consequences of IFRS adoption: Evidence from New Zealand. Journal of International Accounting, Auditing and Taxation, 27, 40-48. https://doi.org/10.1016/ j.intaccaudtax.2016.10.001

Huang, H. W., Rose-Green, E., \& Lee, Ch. Ch. (2012). CEO Age and Financial Reporting Quality. Accounting Horizons American Accounting Association, 26(4), 725-740. https://doi.org/10.2308/acch-50268

Hunton, J. E., Hoitash, R., \& Thibodeau J. C. (2011). The Relationship between Perceived Tone at the Top and Earnings Quality. Contemporary Accounting Research, 28(4), 1190-1224. https://doi.org/10.1111/j.1911-3846.2011.01100.x

Ilieva, M., \& Yamada, J. I. (2018). Decision-Making Process in Japanese Board Room. Audit \& Supervisory Board as a Source of Information to Outside Board Members: A Systematic Review. Journal of Modern Accounting and Auditing, 14(1), 17-34. https://doi.org/10.17265/1548-6583/2018.01.003

Inoue, T. T., \& Wayne, B. (1996). The Choice of Accounting Policy in Japan. Journal of International Financial Management \& Accounting, 7, 1-23. https://doi.org/10.1111/j.1467-646X.1996.tb00061.x

Karagul, A. A., \& Yonet, N. K. (2012). Impact of Board Characteristics and Ownership Structure on Voluntary Disclosure: Evidence from Turkey, Retrieved from www. scholar-google.com.

Kedzior, M., \& Grabinski, K. (2018). Forma prezentacji informacji w sprawozdaniach finansowych a ich uzytecznoscprzeglad wybranych badan, Zeszyty Naukowe Uniwersytetu Ekonomicznego w Krakowie, 2 (974), 41-59. https://doi.org/10.15678/ZNUEK.2018.0974.0203

Kedzior, M. (2012). Capital Structure in EU Selected Countries - Micro and Macro Determinants. Argumenta Oeconomica, 28(1), 69-117.

Khurana I. K., \& Kim M. S. (2003). Relative Value Relevance of Historical Cost vs. Fair Value: Evidence from Bank Holding Companies. Journal of Accounting and Public Policy, 22, 19-42. https://doi.org/10.1016/S0278-4254(02) 00084-4

Klai, N., \& Omri, A. (2013). Corporate Board Characteristics and the Informativeness of Accounting Earnings: Evidence from Tunisia. International Journal of Financial Economics, 1(4), 2013, 133-142.

Kouki, A. (2018). IFRS and value relevance. Journal of Applied Accounting Research, 19 (1), 60-80, https://doi.org/10. 1108/JAAR-05-2015-0041

Lang, M. H., \& Lundholm R. J.(2000). Voluntary Disclosure and Equity Offerings: Reducing Information Asymmetry or Hyping the Stock?. Contemporary Accounting Research, 17(4), 623-662. https://doi.org/10.1506/9N45-F0JXAXVW-LBWJ

Leuz, C., \& Wustemann, J. (2003). The Role of Accounting in the German Financial System, CFS Working Paper, 16. https://doi.org/10.2139/ssrn.427000

Li, S. (2010). Does Mandatory Adoption of International Financial Reporting Standards in the European Union Reduce the Cost of Equity Capital?. The Accounting Review, 85(2), 607-636. https://doi.org/10.2308/accr.2010.85.2.607

Lin, Y. C., Wang, Y. C., Chiou, J. R., \& Huang, H. W. (2014). CEO Characteristics and Internal Control Quality, Corporate Governance: An International Review, 22(1), 24-42. https://doi.org/10.1111/corg.12042

Lo, K., Ramos, F., \& Rogo, R. (2017). Earnings management and annual report readability. Journal of Accounting and Economics, 63(1), 1-25. https://doi.org/10.1016/j.jacceco.2016.09.002

Machuga, S., \& Teitel K. (2009). Board of Director Characteristics and Earnings Quality Surrounding Implementation of a Corporate Governance Code in Mexico. Journal of International Accounting, Auditing and Taxation, 18(1), 1-13. https://doi.org/10.1016/j.intaccaudtax.2008.12.002

Masulis, R., Wang, C., \& Xie, F. (2010). Globalizing the Boardroom - The Effects of Foreign Directors on Corporate Governance and Firm Performance, Working Paper. https://doi.org/10.2139/ssrn.1572838

Matonti, G., \& Iuliano, G. (2012). Voluntary adoption of IFRS by Italian private firms: A study of the determinants. Eurasian Business Review, 2(2), 43-70. 
McClelland, P. L., \& O'Brien, J. P. (2011). Transaction Cost Economics and Corporate Governance: The Case of CEO Age and Financial Stake. Managerial and Decision Economics, 32, 141-158. https://doi.org/10.1002/mde.1520

McClelland, P. L., Liang, X., \& Barker, V. L. (2010). CEO Commitment to the Status Quo: Replication and Extension Using Content Analysis. Journal of Management, 36(5), 1251-1277. https://doi.org/10.1177/0149206309345019

Musteen, M., Barker, V. L., \& Baeten, V. L. (2006). CEO Attributes Associated with Attitude Toward Change: The Direct and Moderating Effects of CEO Tenure. Journal of Business Research, 59, 604-612. https://doi.org/10.1016/ j.jbusres.2005.10.008

Ning, Y., Davidson, W. N., \& Zhong K. (2007). The Varlability of Board Size Determinants: An Empirical Analysis. Journal of Applied Finance, FALL/WINTER, 46-61.

Nobes, C. W., \& Stadler, C. (2015). The qualitative characteristics of financial information, and managers' accounting decisions: evidence from IFRS policy changes. Accounting and Business Research, 45(5), 572-601. https://doi.org/10. 1080/00014788.2015.1044495

Pais, C. A. F., \& Bonito, A. L. M. (2018). The macroeconomic determinants of the adoption of IFRS for SMEs. Revista de Contabilidad-Spanish Accounting Review, 21(2), 116-127. https://doi.org/10.1016/j.rcsar.2018.03.001

Palmer, T. M., \& Varner, I. I. (2007). A Comparison of the International Diversity on Top Management Teams of Multinational Firms Based in the United States, Europe, and Asia: Status and Implications. Singapore Management Review, 29(1), 1-31.

Parlakkaya, R., Akmese, H., \& Cetin, H. (2011). IFRS Consciousness and Adoption: A Research on the Turkish Corporations Listed on Istanbul Stock Exchange. The Business Review, 17(2), 190-196.

Pathak, J., \& Sun, J. (2013). Does Investor Protection Regime Affect the Effectiveness of Outside Directorship on the Board?. Journal of Multinational Financial Management, 23(1), 19-33. https://doi.org/10.1016/j.mulfin.2012.10.004

Petera, P., Wagner, J., Paksiova, R., \& Krehnacova, A. (2019). Sustainability Information in Annual Reports of Companies Domiciled in the Czech Republic and the Slovak Republic. Inzinerine Ekonomika-Engineering Economics, 30(4), 483-495. https://doi.org/10.5755/j01.ee.30.4.22481

Pichler, S., Cordazzo, M., \& Rossi, P. (2018). An analysis of the firms-specific determinants influencing the voluntary IFRS adoption: evidence from Italian private firms. International Journal of Accounting, Auditing and Performance Evaluation, 14(1), 85-104. https://doi.org/10.1504/IJAAPE.2018.089418

Popov, V. (2001). September. Lessons from Transition Economies: Strong Institutions Are More Important than The Speed of Reforms. In UNRISD meeting on 'The Need to Rethink Development Economies', South Africa.

Ran, G., Fang, Q., Luo, S., \& Chan, K. C. (2015). Supervisory board characteristics and accounting information quality: Evidence from China. International Review of Economics \& Finance, 37, 18-32. https://doi.org/10.1016/j.iref. 2014.10.011

Reeb, D. M., \& Zhao, W. (2013). Director Capital and Corporate Disclosure Quality. Journal of Accounting and Public Policy, 32(4), 191-212. https://doi.org/10.1016/j.jaccpubpol.2012.11.003

Rehman, I. U., \& Shahzad, F. (2014). The economic consequences of mandatory IFRS reporting: Emerging market perspective. Inzinerine Ekonomika-Engineering Economics, 25(4), 401-409. https://doi.org/10.5755/j01.ee.25.4.2775

Ruigrok, W., Peck, S., \& Tacheva, S. (2007). Nationality and Gender Diversity on Swiss Corporate Boards. Corporate Governance: An International Review, 15(4), 546-557. https://doi.org/10.1111/j.1467-8683.2007.00587.x

Salem, R. B., Damak-Ayadi, S., \& Saihi, M. (2017). Determinants of full IFRS adoption. International Journal of Managerial and Financial Accounting, 9(2), 105-123. https://doi.org/10.1504/IJMFA.2017.084776

Salvary S. (2006). Fair Value - the Basis of International Financial Reporting Standards: A Conceptual Contradiction of the Relevant Measurement Attribute in Financial Accounting, [in:] G. N. Gregoriou, M. Gaber (editors). International Accounting Standards, Regulations, and Financial Reporting, Elsevier, Oxford 2006, 97-121.

Siregar, S. V., Djakman, C. D., Farahmita, A., \& Setyaningrum, A. (2017). Perceptions of Practitioners, Auditors, and Academics on IFRS Convergence in Indonesia. In International Accounting Conference.

Srinivasan, S. (2005). Consequences of Financial Reporting Failure for Outside Directors: Evidence from Accounting Restatements and Audit Committee Members. Journal of Accounting Research, 43(2), 291-334. https://doi.org/10. 1111/j.1475-679x.2005.00172.x

Sucher, P., \& Jindrichovska, I. (2004). Implementing IFRS: A Case Study of the Czech Republic. Accounting in Europe, 1, 109-141. https://doi.org/10.1080/0963818042000262757

Tarca, A. (2004). International Convergence of Accounting Practices: Choosing between IAS and US GAAP. Journal of International Financial Management \& Accounting, 15, 60-91. https://doi.org/10.1111/j.1467-646X.2004.00102.X 
Marcin Kedzior, Małgorzata Cyganska, Dimitrios Syrrakos. Determinants of Voluntary International Financial Reporting...

Tran, T., Ha, X., Le, T., \& Nguyen, N. (2019). Factors affecting IFRS adoption in listed companies: Evidence from Vietnam. Management Science Letters, 9(13), 2169-2180. https://doi.org/10.5267/j.msl.2019.7.035

Upadhyay, A., \& Sriram, R. (2011). Board Size, Corporate Information Environment and Cost of Capital. Journal of Business Finance \& Accounting, 38(9\&10), 1238-1261. https://doi.org/10.1111/j.1468-5957.2011.02260.x

Vafeas, N. (2000). Board Structure and the Informativeness of Earnings. Journal of Accounting and Public Policy, 19(2), 139-160. https://doi.org/10.1016/S0278-4254(00)00006-5

van Veen, K., \& Marsman, I. (2008). How International are Boards of European MNCs? Nationality Diversity in 15 European Countries. European Management Journal, 26, 188-198. https://doi.org/10.1016/j.emj.2007.12.001

Voulgaris, G., Stathopoulos, K., \& Walker M. (2013). IFRS and the Use of Accounting-Based Performance Measures in Executive Pay. International Review of Financial Analysis, 29, 227-236. https://doi.org/10.1016/j.intacc.2014.10.001

Wang, Z. (2014). Measuring Investors' Assessment of Earnings Persistence: do Investors See Through Smoothed Earnings?. Review of Quantitative Finance and Accounting, 42, 691-708. https://doi.org/10.1007/s11156-013-0358-8

Waniak-Michalak, H., Czajor, P., \& Michalak, J.(2012). Impact of Mandatory IFRS Implementation on Earnings Quality. Evidence from the Warsaw Stock Exchange. Theoretical Journal of Accounting, 68, 63-82.

Wu, J. S., \& Zhang, I. X. (2009). The Voluntary Adoption of Internationally Recognized Accounting Standards and Firm Internal Performance Evaluation. The Accounting Review, 84(4), 1281-1309. https://doi.org/10.2308/accr.2009. 84.4.1281

Yang, J., Chi, J., \& Young, M. (2011). A Review of Corporate Governance in China. Asian\&Pacific Economic Literature, 25(1), 15-28. https://doi.org/10.1111/j.1467-8411.2011.01283.x

Yang, Y., \& Abeysekera, I. (2018). Effect of non-IFRS earnings reporting guidelines on underlying earnings reporting quality: The case of Australian Listed firms. Journal of International Financial Management \& Accounting. https://doi.org/10.1111/jifm.12083

Yasser, Q. R., Al Mamun, A., \& Hook, M. (2017). The impact of ownership structure on financial reporting quality in the east. International Journal of Organizational Analysis, 25 (2), 178-197. https://doi.org/10.1108/IJOA-08-2015-0894

Ye, K., Zhang, R., \& Rezaee, Z. (2010). Does Top Executive Gender Diversity Affect Earnings Quality? A Large Sample Analysis of Chinese Listed Firms. Advances in Accounting, 26(1), 47-54. https://doi.org/10.1016/j.adiac.2010.02.008

Young, S. (1998). The Determinants of Managerial Accounting Policy Choice: Further Evidence for the UK. Accounting and Business Research, 28(2), 131-143. https://doi.org/10.1080/00014788.1998.9728904

Zahid, R. A., \& Simga-Mugan, C. (2019). An Analysis of IFRS and SME-IFRS Adoption Determinants: A Worldwide Study. Emerging Markets Finance and Trade, 55(2), 391-408. https://doi.org/10.1080/1540496X.2018.1500890

The article has been reviewed.

Received in November 2019; accepted in April 2020. 